A279.9 RARE ANND LOCAL TREES Ap. 3 IN THE NATIONAL FORESTS

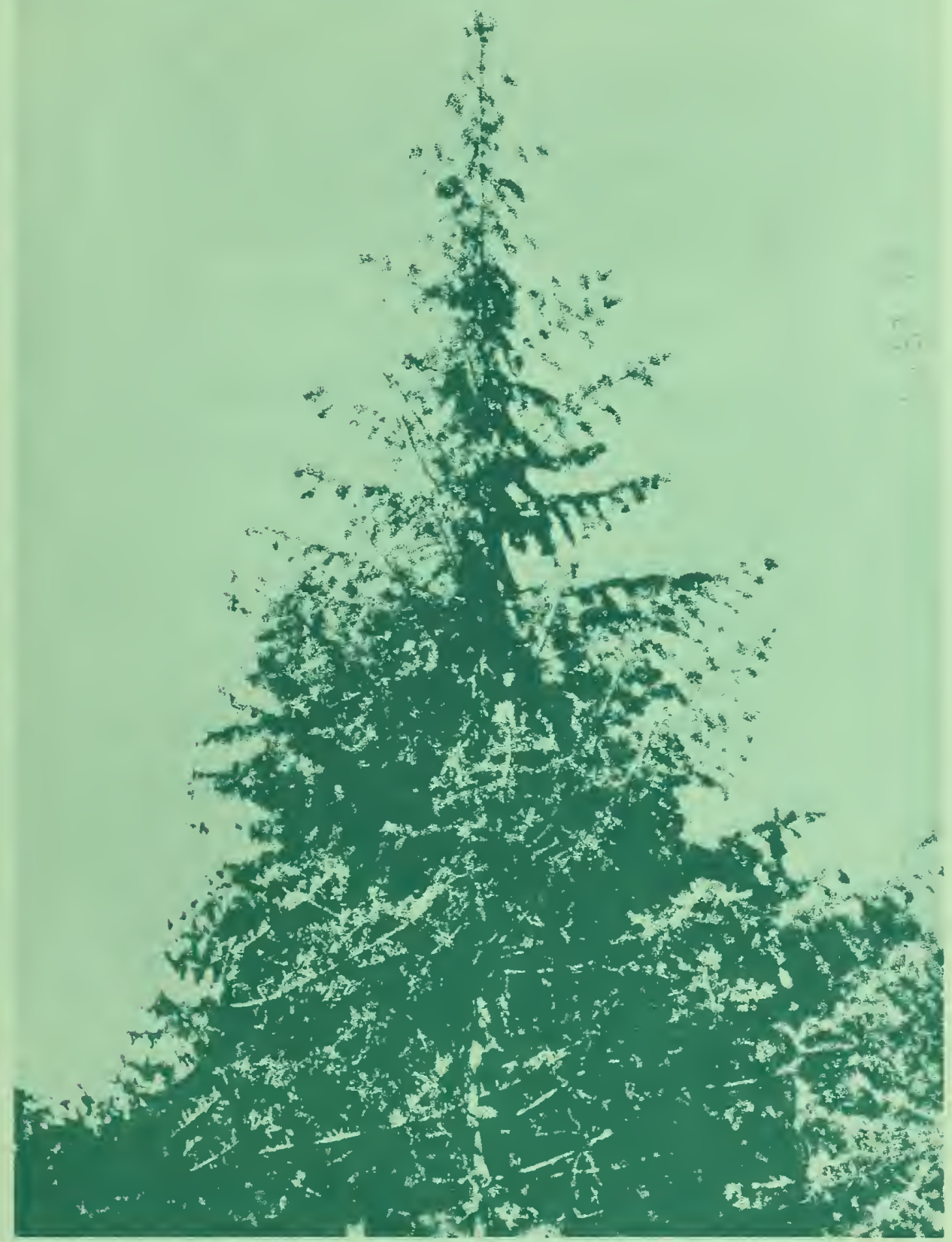

Conservation Research Report No. 21

United States Department of Agriculture-Forest Service Washington, D.C. 20250 June 1977 


\section{Historic, archived document}

Do not assume content reflects current scientific knowledge, policies, or practices. 


\title{
RARE AND LOCAL TREES \\ IN THE NATIONAL FORESTS
}

by

\author{
Elbert L. Little, Jr.
}

Chief Dendrologist, Timber Management Research

U.S. Department of Agriculture, Forest Service

Washington, D.C.

Conservation Research Report No. 21

United States Department of Agriculture - Forest Service

Washington, D.C. 20250 


\section{CONTENTS}

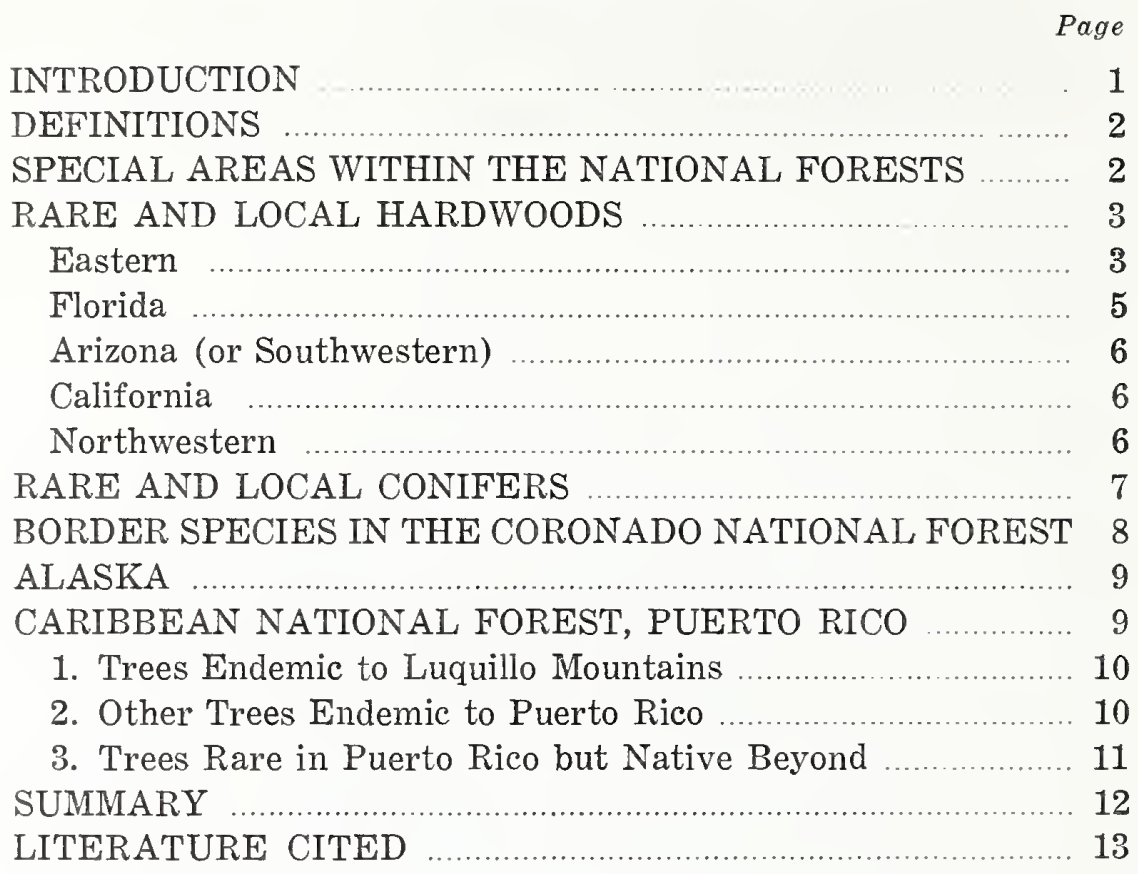

\section{ABSTRACT}

Little, Elbert L., Jr.

1977. Rare and local trees in the National Forests. U.S. Dep. Agric., Conserv. Res. Rep. 21, 14 p.

The National Forests contain and preserve trees of many species that are classed as rare or local in distribution within the country. These include 40 species and several varieties within continental United States and 90 tropical tree species within the Caribbean National Forest of Puerto Rico. Nine tree species and 6 additional varieties on preliminary lists of proposed endangered and threatened plant species of continental United States grow wild within National Forests. This report is the third in a series on rare and local trees.

OXFORD: 174(73).

KEYWORDS: Trees (U.S.) ; rare trees (U.S.) ; rare and endangered plants; tree sanctuaries; trees, distribution.

Cover: Bristlecone fir, Abies bracteata D. Don, also called Santa Lucia fir. Confined to Santa Lucia Mountains, Los Padres National Forest, Calif. 


\title{
RARE AND LOCAL TREES IN THE NATIONAL FORESTS
}

\author{
By Elbert L. Little, Jr.
}

\section{INTRODUCTION}

The National Forests contain and preserve trees of many species that are classed as rare or local in distribution within the United States. This report, the third in a series on rare and local trees, cites these species and the National Forests where each is native. Trees on lists of proposed endangered and threatened plant species are so designated, though none has been so classified officially.

One purpose is to provide a reference list of rare and local trees for land managers. The aim is to bring the list to the attention of the officials in charge of the ranger districts and other areas. The report may help foresters and other land managers, especially those beginning work on the areas in the future, to become aware of these trees and their local distribution. Thus, these species can be considered in management practices, and any needed steps for further protection can be taken.

Also, in the absence of surveys or local plant lists, this compilation may suggest where other rare trees and range extensions might be expected and sought within the National Forests. Credit is due many colleagues for their helpful review of the manuscript.

Forty species and several varieties of trees classed here as rare or local are native within the National Forests of continental United States. Fifteen tree species of Mexican mountains have their main United States distribution within the Coronado National Forest of southeastern Arizona and adjacent New Mexico. Also, 90 tropical tree species found within the Caribbean National Forest of Puerto Rico are included because they are confined to that island (endemic) or are rare.

Lists of proposed endangered and threatened plant species of continental United States contain about 40 species and varieties of trees (Little $1975 \mathrm{~b}^{1}$ ). Nine of these species and 6

\footnotetext{
1 Names and dates in parentheses refer to Literature Cited, p. 13.
}

varieties, classed here also as rare or local, grow wild within at least 16 National Forests in 10 or more States.

"Rare and Local Conifers of the United States" (Little 1975a), the first report in this series, summarizes the occurrence of 35 rare and local species and names the National Forests, National Parks, and other preserves where each is found. Fortunately, only 2 of these rare and local species (not in National Forests) and 2 varieties are tentatively proposed as endangered.

"Rare Tropical Trees of South Florida" (Little 1976a), the second report, compiles the distribution of 60 species of rare tropical trees of the 3 southernmost counties within parks and other preserves. There are no National Forests in South Florida.

The Endangered Species Act of 1973 (U.S. Public Law 93-205) stressed the need for an inventory and authorized the Smithsonian Institution to prepare within 1 year a list of proposed endangered and threatened plant species. The author submitted lists of rare tree species. The preliminary published list (Smithsonian Institution, Secretary 1975) contains more than 2,000 species and varieties in continental United States.

The Act also provides that the Secretary of the U.S. Department of the Interior must study the Smithsonian Institution's preliminary lists of species and determine whether or not any species is truly threatened or endangered. At this time, no plant species has officially been so classified by the Secretary. However, a list of proposed endangered status for some 1,700 United States vascular plant taxa has been published (U.S. Department of the Interior, Fish and Wildlife Service 1976). That list adds Hawaii but omits species proposed earlier as threatened. Thus, the proposed threatened and endangered species of that publication are tentative or preliminary and will remain so until 
the Secretary makes a final determinationpossibly a few years in the future.

This list of rare and local trees in the $\mathrm{Na}$ tional Forest has been assembled from various sources. For many years the Dendrology Project of the Forest Service has been compiling records and maps on tree distribution. The general natural range, by States, of each tree species and variety has been recorded in Forest Service Check Lists (Little 1953). The first checklist was published in 1898.

Also, the 5-volume "Atlas of United States Trees," now being completed, has a map of each native species of continental United States, including all mentioned here. "Volume 1, Conifers and Important Hardwoods" (Little 1971a) contains maps of all native conifers. "Volume 2, Alaska Trees and Common Shrubs" (Viereck and Little 1975) covers that State. The other trees will be found in "Volume 3, Minor Western Hardwoods" (Little 1976b) and "Volume 4, Minor Eastern Hardwoods" (Little 1977).

Detailed maps of forest trees in California have been published (Griffin and Critchfield 1972). Much earlier, George B. Sudworth (1913), the first Forest Service dendrologist, began preparation of species maps but issued only the first part entitled "Forest Atlas. Geographic Distribution of North American Trees."

Maps of the tree species on lists by the Smithsonian Institution were compared with a map of the National Forests, both with the same scale, $1 / 10,000,000$. Then the species whose ranges included National Forests were checked for more detailed records, such as State and local floras and monographs.

\section{DEFINITIONS}

Several descriptive definitions may be appropriate. A rare species has small numbers of individuals throughout its range, which may be restricted or widespread. The term local species is used here for one of relatively small range but one which is sufficiently common not to be called rare. A species whose range is limited to a particular named area, usually small, is cited as endemic. Border or peripheral species reach the limit of their natural range a short distance into the United States, where they may be classed also as rare or local. (Border species could become extinct in the United States and still be common in a neighboring country.)

Two administrative or legal definitions may be quoted from the Endangered Species Act. "The term 'endangered species' means any species which is in danger of extinction through- out all or a significant portion of its range...." "The term 'threatened species' means any species which is likely to become an endangered species within the foreseeable future throughout all or a significant portion of its range." Survival of an endangered species requires assistance. When a species has small numbers of individuals, loss of or changes in habitat, overexploitation, competition, disease, or other factors could cause extinction. At present, no plant species has been officially classified as endangered or threatened.

Some rare and local tree species are also on the lists of proposed endangered and threatened species compiled by the Smithsonian Institution (1975). However, border or peripheral species generally are excluded by definitions.

\section{SPECIAL AREAS WITHIN THE NATIONAL FORESTS}

Many rare and local plant species are protected within Federal lands administered by the Forest Service and other agencies (Little 1975a). For example, more than 500 Research Natural Areas have been established on Federal lands for scientific and educational purposes, and action on others is pending. A directory compiled in 1968 listed 336 (Federal Com- mittee on Research Natural Areas 1968). Federal Research Natural Areas in Oregon and Washington, totaling 48 in 1972 , have been described in detail (Franklin, Hall, Dyrness, and Maser 1972).

The National Forest System is one of the largest and most extensive land acreages managed by an agency. Totals as of Sept. 30, 1976, are 
154 National Forests containing 183,380,761 acres and 19 National Grasslands with 3,808,500 acres (USDA Forest Service 1977).

A high objective in the policy of the Forest Service is to give special emphasis to protection of rare and endangered plants and animals (USDA Forest Service 1970a). The National Forests provide some protection for rare plants through regulation of uses such as sales of timber and minor forest products and the grazing of livestock. Commercial harvesting, collecting, and other human activities are administered or restricted by law.

Within the National Forests are many special areas under administrative designation and management with emphasis on particular features or objectives. For example, there are 21 National Game Refuges and National Wildlife Preserves.

These special areas give further protection to many representative samples of undisturbed vegetation and to rare plants. Though under regulation, many of these areas are subject to some risks from public use. Nevertheless, the vegetation types containing rare plants have some preservation against disturbance and destruction of the habitats. Plants so guarded still could be threatened by diseases, insect pests, fire, or other natural causes. Some rare plants in the National Forests may require special attention in management.

Research Natural Areas established in the National Forests for scientific and educational purposes total 123 in 29 States and Puerto Rico. Research is concentrated in a series of Experimental Forests located in representative forest types over the country. A portion of each Experimental Forest generally is maintained in natural condition as a check for comparison with experimental plots.

The largest acreage given special protection within the National Forests is administered under the National Wilderness Preservation System, which includes areas managed also by agencies of the Department of the Interior. Under the Wilderness Act of 1964 and earlier regulations, large areas are maintained in natural condition for their wilderness or primitive character without roads and commercial timber harvesting (USDA Forest Service 1970b, 1971). As of Sept. 30, 1976, within the National Forests there were 89 Wildernesses totaling 12,368,172 acres and 17 Primitive Areas totaling $3,266,750$ acres. Many rare plant species, especially those of scattered distribution on high mountain peaks and ranges, are protected within these boundaries.

Also, the Forest Service administers 124 Special Interest Areas within the National Forests. These areas contain many small examples of natural and near natural vegetation including some rare plants. The 64 Scenic Areas are preserved primarily for their scenic values and partly for recreation.

Smaller numbers of areas are classed as Historical, Archeological, Geological, and Botanical. Other special types include National Recreation Areas, National Wild and Scenic Rivers, National Recreation Trails, and National Scenic Trails.

The 8 Botanical Areas preserve rare plant species and vegetation types, such as conifers and groves of big trees. The largest and best known is Ancient Bristlecone Pine Forest Botanical Area, 27,160 acres in the Inyo National Forest in California.

\section{RARE AND LOCAL HARDWOODS}

The tree species of the United States that are classed as rare or local, and which grow wild within the National Forests, are listed here. Trees on preliminary lists of proposed endangered and threatened plant species compiled by the Smithsonian Institution (1975) are so designated, though none has been so classified officially.

The rare and local hardwoods in the National Forests of continental United States, totaling 14 species and 4 varieties, have been grouped below by 5 geographical regions : Eastern, Florida, Arizona (or Southwestern), California, and Northwestern. Within each region the species are arranged alphabetically by scientific name. Conifers, which are treated in first report (Little 1975a), follow in a separate summary. Additional topics are devoted to border species in the Coronado National Forest in Arizona and New Mexico, to rare trees in the National Forests of Alaska, and to rare and endemic trees in the Caribbean National Forest in Puerto Rico.

\section{Eastern}

The first geographical region, Eastern United States, contains the 8 tree species listed below. Five are present inside National Forests, and 3 
are to be sought within. Several others restricted to Florida are grouped in the second region, Florida.

Ozark chinkapin, Castanea ozarkensis Ashe. Scattered in mountains and hills of Ozark and and Ouachita Mountains. Southern Missouri (5 counties including Mark Twain National Forest) ; northern, central, and western Arkansas (noted from 15 counties, Ozark and Ouachita National Forests); and eastern Oklahoma (8 counties, Ouachita National Forest). Perhaps it is the only tree species endemic to the Ozark Mountain region (Little 1971b, map 27). Not rare but classed as endangered because of its susceptibility to the chestnut blight disease caused by an introduced parasitic fungus ( $E n$ dothia parasitica). This species from mountains in 3 States probably would be classed better as threatened. The disease has not caused the rerelated American chestnut (Castanea dentata (Marsh.) Borkh.) to become extinct or to be listed as endangered. Control measures would not be practicable.

American smoketree, Cotinus obovatus Raf. (Little 1971b, map 29). Rare and local, mountains of southern Tennessee, northern Alabama, southwestern Missouri, Arkansas, and eastern Oklahoma. Also common on Edwards Plateau, central Texas, and at one locality in Kentucky, perhaps introduced. Missouri: Mark Twain National Forest, within range, recorded from Stone, Taney, Ozark, and Douglas Counties. Arkansas: Ozark National Forest, including Blanchard Springs Caverns area of Sylamore Ranger District, St. Francis National Forest, Stone County (Browne 1974), and Henry R. Koen Experimental Forest, Newton County.

Corkwood, Leitneria floridana Chapm. Rare and local, added to the list of proposed threatened species. Coastal plain in 17 counties of 5 States: southeastern Georgia, northwestern Florida, southeastern Texas, eastern Arkansas, and southeastern Missouri (Channell and Wood 1962). Recorded from lower part of Apalachicola River Valley in Franklin and Gulf Counties, northwestern Florida, apparently a few miles outside the southwestern extension of Apalachicola National Forest in northwestern Franklin County and to be sought within. This shrub or small tree with very lightweight wood is so distinct from all other plants that it is in a separate family, Leitneriaceae.

Pinckneya, Pinckneya pubens Michx. ( $P$. bracteata Raf.). Rare, and scattered, proposed as threatened. Coastal plain of extreme southern South Carolina (Beaufort County), southern Georgia (many counties from Schreven south- east to Randolph and southward), and northeastern to northwestern Florida (several counties from Nassau to Volusia and west to Gulf and Jackson). In northwestern Florida within Apalachicola National Forest, which coincides with the range in Leon, Wakulla, and Liberty Counties. At Orange Springs, Marion County, adjacent to Ocala National Forest and to be sought within. "One of the most spectacularly beautiful" small trees in northern Florida in flower, because of the greatly expanded rosepink elliptic calyx lobes of some flowers (Kurz and Godfrey 1962).

Allegheny plum, Prunus alleghaniensis Porter. Shrub or small tree local and scattered in Appalachian Mountains, proposed as threatened. Mainly from central Pennsylvania ( 7 counties from Clearfield and Centre southward) to eastern West Virginia (6 counties south to Monroe). Reported from mountains of western Virginia (Rockbridge County) and northeastern Tennessee (Grainger County). Also rare in southern Connecticut (3 counties). West Virginia: Monongahela National Forest, Pendleton County (Clarkson 1966).

Georgia oak, Quercus georgiana M. A. Curtis. Rare and local, mostly in Piedmont, proposed as threatened. South Carolina, Spartanburg and Kershaw Counties; northern and western Georgia, noted from 7 counties (Jones 1974); and Alabama ( 2 counties). To be sought within these National Forests: South Carolina: Sumter; Georgia, Oconee; and Alabama, Talladega. In Georgia, Wilbur H. Duncan (personal communication) reports that this species is very uncommon but abundant in its outcropping habitat and is reproducing well, thus not to be proposed as threatened.

Oglethorpe oak, Quercus oglethorpensis Duncan. Rare and local in the Piedmont of northeastern Georgia and western South Carolina (Duncan 1950, fig. 1), proposed as threatened. "Many places" in Georgia within an area about 25 miles long and 10 miles wide across Oglethorpe, Elbert, and Wilkes Counties. Also nearby in South Carolina within an area of similar size in 4 counties (McCormick, Edgefield, Greenwood, and Saluda). Apparently within the Sumter National Forest, whose area extends across the first three named counties of South Carolina. According to Wilbur H. Duncan (personal communication), who named this species in 1940 , about nine-tenths of the habitat has been destroyed because of intensive silvicultural practices.

Kelsey locust, Robinia kelseyi Hutchins. An ornamental shrub or small tree with pink 
flowers, possibly of hybrid origin, and known from mountains of western North Carolina ( 7 counties) and eastern Tennessee (4 counties). Rare and local but protected by introduction into cultivation in 1901 (Dayton 1943). North Carolina: collected in Yancey County within Pisgah National Forest and in Avery County, where this National Forest also occurs. Apparently not yet known from Great Smoky Mountains National Park in both States.

Ashe birch, Betula uber (Ashe) Fern. ( $B$. lenta var. uber Ashe) was classed as probably extinct until rediscovered in 1975. It was named in 1918 from Smyth County, southwestern Virginia, apparently near the Jefferson National Forest. Rediscovery was reported by Ogle and Mazzeo (1975, 1976). Reed (1975) concluded that the few trees found on private land had been planted and that they probably represented the hybrid between yellow birch, $B$. alleghaniensis Britton, and low birch, B. pumila L. var. glandulifera Reg., and known also as Purpus birch, B. × purpusii C. K. Schneid. If shown to be an artificial hybrid, this birch should be removed from lists of both native and rare trees.

\section{Florida}

Four local species and 2 local varieties of hardwoods are found within Florida's 3 National Forests. One is within Apalachicola National Forest in the northwestern part of the State. Another is to be sought in Osceola in the northern part.

Ocala National Forest, in the north central part, has 3 of the local species and the 2 local varieties. It is of special interest as the southernmost National Forest in continental United States. The sand hill or lake region of central Florida is characterized by scrub vegetation of everygreen oaks and sand pine as well as hammocks with broadleaf evergreens. This region where temperate and subtropical plants meet is also a center of local species. However, very few tropical trees extend so far north, according to a recent list of the woody plants (Mohlenbrock 1976).

Southern Florida, which lacks National Forests, has many tropical tree species absent northward. The rare tropical trees of South Florida were the subject of the second report in this series.

Scrub hickory, Carya floridana Sarg. A shrub or small tree of scrub vegetation on sandy ridges of central Florida from Volusia and Marion south to Charlotte and Palm Beach Counties, in- cluding Ocala National Forest in Marion County (Ward 1963). This local species is not rare.

Dune holly, Ilex opaca var. arenicola (Ashe) Ashe. A variety of American holly (Ilex opaca Ait.), distinguished as a shrub or small tree on dry sandy sites in sand pine-evergreen oak scrub having smaller, stiffer leaves. Northeastern to central Florida (Clay to Highlands Counties), through the Ocala National Forest. Proposed as threatened, perhaps because its evergreen, leathery, spiny leaves, and large red berries are a source of Christmas decorations. Recorded as common in the scrub vegetation of the southern part of the Florida lake region and less common northward.

Yellow anise-tree, Illicium parviflorum Michx. A large spreading shrub or small tree rare and local in east central Florida, proposed as threatened (Smith 1947, fig. 8). Recorded from 5 counties: Marion, Volusia, Seminole, Lake, and Polk. Ocala National Forest: Lake George, Lake Kerr, and Juniper Springs Recreation Area in Marion County and Alexander Springs in Lake County.

Ashe magnolia, Magnolia ashei Weatherby. A small tree or shrub, proposed as threatened, local in northwestern Florida in the Coastal Plain along the Gulf of Mexico. Recorded from 8 counties, Leon and Wakulla west to Santa Rosa. Within the boundaries of Apalachicola National Forest in upland woodlands along the Ochlockonee River, Wakulla and Leon Counties, also Liberty County (Kurz and Godfrey 1962). The scientific and common names honor the discoverer, William Willard Ashe (1872-1932) of the USDA Forest Service. This species is closely related to bigleaf magnolia, Magnolia macrophylla Michx., which has wider distribution northward.

Silkbay, Persea borbonia (L.) Spreng. var. humilis (Nash) Kopp ( $P$. humilis Nash). Proposed as threatened. A compact shrub 6-10 ft. high or a small tree in scrub vegetation on sand hills of central Florida and extending northward (Kopp 1966). Collected in Marion and Lake Counties and apparently within Ocala National Forest.

Florida willow, Salix floridana Chapm. Rare, proposed as endangered. A shrub or very small tree reported as "a rare species apparently on the verge of extinction" (Ball 1943). Recorded from southern Georgia (Pulaski and Early Counties, the plants in the first locality probably destroyed), and from northern Florida (Columbia, Levy, Putnam, Marion, Lake, and Orange Counties). Originally described from Jackson County (Marianna) but not found there in 
recent years. Collected a few miles from Juniper Springs in Marion County within the Ocala National Forest. To be sought within the Osceola National Forest.

\section{Arizona (or Southwestern)}

The National Forests of Arizona contain 2 species and 2 varieties of rare and local hardwoods proposed as threatened or endangered. These are listed below. The first has a wider range in 4 southwestern States. Border species on the Coronado National Forest are mentioned separately.

Knowlton hophornbeam, Ostrya knowltonii Cov. (O. baileyi Rose). Rare, proposed as threatened. Local and scattered in mountains, valleys, and canyons of 4 southwestern States. Guadalupe Mountains (National Park) in Culberson County, Trans-Pecos Tex. Southern New Mexico: Lincoln National Forest, Guadalupe Mountains in Eddy County and Sacramento Mountains in Otero County. Northern Arizona: Coconino National Forest, Oak Creek Canyon Natural Area in Coconino County, and Grand Canyon National Park (type locality). Also local in Mohave and Yavapai Counties and to be sought in Kaibab and Prescott National Forests. Southeastern Utah: Manti-LaSal National Forest in San Juan County and various localities along Colorado River in San Juan, Kane, Garfield, and Grand Counties.

Lowell ash, Fraxinus anomala Torr. var. lowellii (Sarg.) Little ( $F$. lowellii Sarg.). Rare, proposed as threatened. A shrub or small tree local in mountains, mostly along streams, known only from northern and central Arizona. The range is nearly confined to these National Forests in the counties indicated: Kaibab (Coconino County), Coconino (Coconino County), Prescott (Yavapai County), Tonto (Gila and eastern Maricopa Counties), and Coronado (Graham County). Also eastern Mohave County. The type locality of this variety is Grand Canyon National Park.

Fragrant ash, Fraxinus cuspidata Torr. var. macropetala (Eastw.) Rehd. ( $F$. macropetala Eastw.). Rare, proposed as threatened. Shrub or small tree local in mountains and canyons of northern and central Arizona. Kaibab and Cococino National Forests and Grand Canyon National Park (type locality of variety) in Cococino County, and Tonto National Forest in Gila County. Also in western Navajo and northeastern Mohave Counties. Erroneously reported from southern Nevada.
Goodding ash, Fraxinus gooddingii Little. Rare, proposed as endangered. A small tree rare and local in Sycamore Canyon within Goodding Natural Area, Coronado National Forest, on the Mexican border in Santa Cruz County, southern Arizona. Discovered in 1934 and named in 1952. This is the type locality and only one known in the United States. Also in mountains of adjacent northeastern Sonora.

Another rare shrub or small tree proposed as threatened should be noted. Vauquelinia pauciflora Standl. is known in the United States only from the type locality near Guadalupe Canyon, Cochise County, in extreme southeastern corner of Arizona along the Mexican border. This stand is at a lower altitude near but outside the boundary of a division of the Coronado National Forest and earlier was cited from Sonora and New Mexico (Wells and Johnson 1964). The same or a closely related species has been found in adjacent northern Mexico.

\section{California}

The rare and proposed endangered tree species of California are mostly outside the $\mathrm{Na}$ tional Forests except for several conifers listed here. Two hardwood species have local distribution in National Forests of southwestern California.

California walnut, Juglans californica S. Wats. Common locally in oak woodland of coastal southern California from Santa Ynez Mountains southeast to Santa Ana Mountains (Griffin and Critchfield 1972, map 30). Apparently within Los Padres National Forest in Santa Barbara and Ventura Counties and within Cleveland National Forest in Orange and Riverside Counties. Introduced and becoming established beyond the natural range.

Engelmann oak, Quercus engelmannii Greene. This medium-sized tree has a limited distribution in hills and coast range in 4 counties of southwestern California and adjacent northwestern Baja California (Griffin and Critchfield 1972, map 71). Angeles National Forest in Los Angeles County, San Bernardino National Forest in Riverside County, and Cleveland National Forest in Orange, Riverside, and San Diego Counties.

\section{Northwestern}

River willow, Salix fuviatilis Nutt. The only tree species of Northwestern United States proposed as threatened. A shrub or small tree, rare 
and local along Columbia River in southwestern Washington and northwestern Oregon and south in Willamette Valley of northwestern Oregon. Within range of Mt. Hood National Forest, which borders Columbia River along northern boundaries of Hood River and Multnomah Counties, northwestern Oregon.

\section{RARE AND LOCAL CONIFERS}

Thirty-five of the 96 species of conifers native in continental United States, more than onethird, are trees of rare or local distribution, according to a recent compilation (Little 1975a). That publication, which contains further information not repeated here, summarizes distribution of each species on a map and cites the public forests, parks, and other preserves. Fortunately, only 2 coniferous species local in Florida, both outside National Forests, were proposed as endangered. However, 2 varieties (or 2 species) of cypress (Cupressus) on $\mathrm{Na}$ tional Forests were so listed.

Twenty-six of these species and additional varieties of rare and local conifers are native within one or more National Forests. Several have their natural distribution almost entirely within the National Forests or also other public preserves nearby and merit mention. Thus, further information should be available to local foresters and other land managers.

Two coniferous species of limited occurrence at high altitudes in the southern Appalachians are mostly within the National Forests. Fraser fir, Abies fraseri (Pursh) Poir., common locally, is within these 4 National Forests: Jefferson in Virginia, Pisgah and Nantahala in North Carolina, and Cherokee in Tennessee. Carolina hemlock, Tsuga caroliniana Engelm., is local and scattered, chiefly within the same 4 National Forests, and also Chattahoochee in South Carolina and Georgia.

The other rare conifers chiefly confined to National Forests are western and mostly in California, the home of many local or endemic plant species. Two pines occupy relatively small areas. Foxtail pine, Pinus balfouriana Grev. \& Balf., is local near a timeberline within Klamath, Shasta, Trinity, and Mendocino National Forests in northern California and within Inyo and Sequoia, also 2 National Parks, in southern Sierra Nevada. Washoe pine, Pinus washoensis Mason \& Stockwell, is very rare and restricted. It was discovered at Mt. Rose, Toiyabe National Forest, Washoe County, western Nevada, and named in 1945. Later it was found at a few areas in mountains of northeastern California, including Toiyabe, Modoc, and Plumas National Forests.
Four other rare conifers of California, each in a different genus, may be noted. Bristlecone fir, Abies bracteata, D. Don, also called Santa Lucia fir, is confined to Santa Lucia Mountains within the Monterey Ranger District, Los Padres National Forest, Monterey County and extreme northwestern San Luis Obispo County. (See cover photograph.) This unique fir, isolated from all related species, has been placed in a separate subgenus because of great differences from other true firs of the world. The entire natural range of this most restricted of all firs consists of scattered areas within a strip about 60 miles long and 13 miles wide.

Brewer spruce, Picea breweriana S. Wats., is mostly within 5 National Forests: Six Rivers, Klamath, and Trinity in California and Siskiyou and Rouge River in Oregon. Bigcone Douglas-fir, Pseudotsuga macrocarpa (Vasey) Mayr, is mainly within these 4 National Forests of southern California: Los Padres, Angeles, San Bernardino, and Cleveland. Giant sequoia, Sequoiadendron giganteum (Lindl.) Buchholz (Sequoia gigantea Lindl.), is local in 70 groves along California's Sierra Nevada for 270 miles. These scattered groves are 99 percent publicly owned within Eldorado, Stanislaus, Sierra, and Sequoia National Forests, 3 National Parks, and 3 State preserves.

Cypresses (genus Cupressus) are the rarest group of native conifers, totaling 7 species further divided into 12 taxonomic groups or taxa (Little 1970a), 8 of these within National Forests. Detailed maps have been published by Griffin and Critchfield (1972). Cuyamaca cypress, Cupressus arizonica var. stephensonii (C. B. Wolf) Little (C. stephensonii C. B. Wolf) is the rarest of the named cypresses and proposed as threatened. It is known from a single grove less than 1 mile long in Cuyamaca Mountains, San Diego County, southern California, within the Cleveland National Forest and Cuyamacha Rancho State Park. A nearby grove now dead has been noted (Griffin and Critchfield 1972, map 28). Recently recorded also from northern Baja Calif., Mexico (Moran 1977).

Piute cypress, Cupressus arizonica var. nevadensis (Abrams) Little (C.nevadensis Abrams), is rare and has been proposed as threatened. It 
is restricted to 9 or more groves in Piute Mountains and vicinity, Kern and Tulare Counties, south-central California. Protected within the Piute Cypress Botanical and Natural Area of the Bakersfield District of the Bureau of Land Management and the Sequoia National Forest, also the Bodfish Botanical Area on this National Forest.

The distribution of 13 of the 26 species of rare and local conifers within the National Forests has been summarized from the earlier publication. Four other species of pine (Pinus) are cited below under Border Species.

To complete the list, the remaining 9 species of conifers, local but not rare within 1 or more National Forests, are mentioned here.

Port-Orford-cedar, Chamaecyparis lawsoniana (A. Murr.) Parl.: Klamath, Shasta-Trinity, Siskiyou, Siuslaw, Six Rivers National Forests.

Ashe juniper, Juniperus ashei Buchholz: Mark Twain, Ozark.

Pinchot juniper, Juniperus pinchotii Sudw.: Lincoln.

subalpine larch, Larix lyallii Parl.: $12 \mathrm{Na}$ tional Forests in mountains of western Montana, northern Idaho, and north-central Washington.

bristlecone pine, Pinus aristata Engelm.: 17 National Forests in high mountains of Colorado, New Mexico, Arizona, Utah, Nevada, and California.

sand pine, Pinus clausa (Chapm.) Vasey: Ocala.

Coulter pine, Pinus coulteri D. Don: Angeles, Cleveland, Los Padres, San Bernardino. southwestern white pine, Pinus strobiformis Engelm.: Apache-Sitgreaves, Cibola, Coconino, Gila, Lincoln.

California torreya, Torreya californica Torr.: Eldorado, Lassen, Mendocino, Plumas, Sequoia, Sierra, Stanislaus, Tahoe.

Two other related cypresses are less rare. Arizona cypress (typical) or Arizona rough cypress, Cupressus arizonica Greene var. arizonica, is represented within the Coronado and Apache National Forests in Arizona and also Big Bend National Park and 2 National Monuments. Arizona smooth cypress, Cupressus arizonica var. glabra (Sudw.) Little (C. glabra Sudw.), is within these 4 National Forests of Arizona: Coconino, Kaibab, Prescott, and Tonto.

Modoc cypress, Cupressus bakeri Jeps., also called Baker cypress and Siskiyou cypress, is known from these 4 National Forests: Lassen, Klamath, and Plumas in northern California and Rogue River in southwestern Oregon. Tecate cypress, Cupressus guadalupensis S. Wats. var. forbesii (Jeps.) Little (C. forbesii Jeps.), has several groves in southern California and northwestern Baja California. One grove is in the Cleveland National Forest. MacNab cypress, Cupressus macnabiana A. Murr., the most widely distributed cypress in California, is recorded from more than 30 groves in the northern part of the State. One grove is within the Mendocino National Forest. Sargent cypress, Cupressus sargentii Jeps., the second most widely distributed cypress in California, has about 20 groves in the coast ranges and is within 2 National Forests, Mendocino and Los Padres.

\section{BORDER SPECIES IN THE CORONADO NATIONAL FOREST}

Numerous plant species with ranges chiefly in Mexico extend northward across the border into the southern portions of Texas, New Mexico, Arizona, and California. These border or peripheral species by definition are excluded from lists of proposed endangered or threatened species, even though rare or local in the United States. Most of these Mexican plants are from nonforested lowlands and are absent from the National Forests. However, Parry pinyon, Pinus quadrifolia Parl., of northern Baja California, is rare in mountains of southern California, mostly within San Bernardino and Cleveland National Forests.

The Coronado National Forest within its 11 mountainous divisions contains the northernmost individuals of many plant species of the
Cordillera Occidental of northwestern Mexico. It touches the international boundary in southeastern Arizona and nearly so in the southwestern corner of New Mexico.

Tree species of Mexican mountains whose distribution in the United States is confined mainly to the Coronado National Forest are listed below. These include 3 species of pines and 12 of hardwoods. A few extend beyond in smaller numbers to nearby National Forests. Ranges and other notes are contained in references for tree identification, such as "Southwestern Trees" (Little 1950).

Mexican pinyon, Pinus cembroides Zucc. (also Apache and Gila National Forests and southwestern Texas)

Chihuahua pine, Pinus leiophylla Schiede \& 
Deppe var. chichuahuana (Engelm.) Shaw (to central Arizona; also Gila and Tonto National Forests)

Apache pine, Pinus engelmannii Carr.

Schotts yucca, Yucca schottii Engelm.

Bonpland willow, Salix bonplandiana H.B.K.

to Trans-Pecos Texas)

yewleaf willow, Salix taxifolia H.B.K. (also

to Trans-Pecos Texas)

netleaf oak, Quercus rugosa Née (Q. reticulata Humb. \& Bonpl.)

Mexican blue oak, Quercus oblongifolia Torr.
Toumey oak, Quercus toumeyi Sarg.

silver oak, Quercus hypoleucoides A. Camus

Torrey vauquelinia, Vauquelinia californica

(Torr.) Sarg.

kidneywood, Eysenhardtia polystachya (Or-

tega) Sarg.

southwestern coralbean, Erythrina flabelliformis Kearney

Arizona madrone, Arbutus arizonica (A. Gray) Sarg.

Chihuahua ash, Fraxinus papillosa Lingelsh.

\section{ALASKA}

Alaska has no native tree species proposed as endangered or threatened. Most of the coastal spruce-hemlock forests of southeastern and southern Alaska-are within the State's $3 \mathrm{Na}$ tional Forests. Proposals for additional National Forests in the interior, where additional tree species occur, have been submitted to Congress.

The rare tree species of the 49 th State have been noted and mapped in other publications (Viereck and Little 1972, p. 10-11; 1975). Not one of the 32 native tree species or 6 shrub species rarely reaching tree size is confined to Alaska or endemic. One tree variety restricted to Alaska and accepted by some authors as a species is Kenai birch, Betula papyrifera var. kenaica (W. H. Evans) Henry ( $B$. kenaica W. H. Evans.) Its range is partly within Chugach National Forest.

A few tree species rare and local near their northwestern limits within the National Forests of southeastern Alaska are mentioned because of the great geographic separation from the lower 48 States. Perhaps small groves merit special protection within designated natural areas.

Hooker willow, Salix hookeriana Barratt, in
Alaska is confined mostly to the Yakutat Bay region within the North Tongass and Chugach National Forests. For many years it was regarded as a local or endemic species Yukatat willow, S. amplifolia Cov. The nearest trees of the same species are about 500 miles southeast in Queen Charlotte Islands. The main distribution is southward along the Pacific Coast from southwestern British Columbia to northwestern California.

Two conifers are rare at their northern limit in extreme southeast Alaska within South Tongass National Forest: Pacific yew, Taxus brevifolia Nutt., and Pacific silver fir, Abies amabilis (Dougl.) Forbes. The Rocky Mountain or inland variety of lodgepole pine, Pinus contorta var. latifolia Engelm., reaches Alaska only in the vicinity of Skagway and Haines near the northern end of southeast Alaska within North Tongass National Forest. Subalpine fir, Abies lasiocarpa (Hook.) Nutt., and western paper birch, Betula papyrifera var. commutata (Reg.) Fern., enter southeast Alaska only near the northern end within North Tongass National Forest and near the southern end within South Tongass National Forest.

\section{CARIBBEAN NATIONAL FOREST, PUERTO RICO}

The largest number or rare tree species anywhere in the National Forest System is found within the Caribbean National Forest in northeastern Puerto Rico. These tropical trees outside continental United States were not included in the first preliminary list of the Smithsonian Institution (1975). However, a separate list for Puerto Rico is in preparation.

Incidentally, Hawaii has no National Forests and is omitted from this report. The 50th State has more endemic tree species than any other (more than 360 have been named). They are mainly local and scattered over several islands.

The Caribbean National Forest (known also as the Luquillo Experimental Forest) contains almost half of the Luquillo Mountains, including the highest peaks, and totals 28,000 acres. Within it is the Baño de Oro Research Natural 
Area of 1,840 acres. This National Forest with a remnant of natural vegetation originated in a forest reserve formerly under the Spanish crown.

The rare and endemic trees of Puerto Rico and the Virgin Islands will be the subject of another report in this series and have been described in the 2-volume illustrated reference on the trees of these islands (Little and Wadsworth 1964; Little, Woodbury, and Wadsworth 1974, p. 15-19, iv-xiv). Lists of the endemic trees and other trees of the Caribbean National Forest have been prepared (Little 1970b, Little and Woodbury 1976).

Within the Caribbean National Forest are 225 species of native trees, more than in any other equal area of the United States. The number is about two-fifths of the 547 species of trees native in Puerto Rico and the Virgin Islands. Of the 142 tree species endemic or confined to these islands, 68 , or nearly one-half, grow wild within this National Forest. In addition, this National Forest has 22 of about 100 other tree species native beyond Puerto Rico and the Virgin Islands that are classed as rare within these islands.

Thus, 90, or two-fifths, of the 225 tree species native within the Caribbean National Forest are classed as endemic or rare. None of the 90 grows wild within continental United States. Most are not closely related to the temperate species listed for the other National Forests. Some belong to unfamiliar plant families characteristic of the tropics.

The 90 species of endemic and rare trees of the Caribbean National Forest may be grouped into three lists, as follows:

1. Trees endemic to Luquillo Mountains, 23 species (including 9 also in nearby Carite Commonwealth Forest).

2. Other trees endemic to Puerto Rico, 45 species (including 2 also in Vieques and 1 of these in St. Croix).

3. Trees rare in Puerto Rico but native beyond, 22 species.

The extent of this valuable living collection of endemic and rare trees is best shown by publication of the lists, as under the other National Forests. In the three lists the species with scientific and common names are numbered in botanical order as in the 2-volume reference cited above. Numbers 1-250 are in the first volume and 251-750 in the second. Several endemic or local species are designated as not rare, being common locally. A few have slightly broader range, as mentioned. Brief notes on rarity have been added.

\section{Trees Endemic to Luquillo Mountains}

The list of 23 tree species endemic to Caribbean National Forest and Luquillo Mountains includes 9 which range also slightly beyond into nearby Carite Commonwealth Forest. Most of the 14 confined to the Luquillo Mountains have their entire natural range within the Caribbean National Forest. Thus, the Forest Service has sole responsibility for management and protection, so that these species will not become endangered or extinct.

35. Magnolia splendens Urban, laurel sabino (not rare)

120. Croton poecilanthus Urban, sabinón (not rare)

160. Laplacea portoricensis (Krug \& Urban) Dyer, maricao verde

212. Micropholis garciniifolia Pierre, caimitillo verde (not rare; also Carite)

237. Tabebuia rigida Urban, roble de sierra (not rare)

239. Antirhea obtusifolia Urban, quina (not rare; also Carite)

284. Myrica holdridgeana Lundell, palo de cera 401. Ravenia urbanii Engler, tortugo prieto (also Carite)

465. Ilex sintenisii (Urban) Britton (not rare; also Sierra de Naguabo)

512. Ternstroemia heptasepala Krug \& Urban

513. Ternstroemia luquillensis Krug \& Urban

536. Xylosma schwaneckeanum (Krug \& Urban) Urban (also Carite)

553. Calyptranthes luquillensis Alain

564. Eugenia borinquensis Britton, guayabota de sierra (not rare; also Carite)

570. Eugenia haematocarpa Alain, uvillo

589. Marlierea sintenisii Kiaersk, beruquillo

600. Miconia foveolata Cogn., camasey

621. Tetrazygia urbanii Cogn., camasey (also Carite)

632. Ardisia luquillensis (Britton) Alain, mameyuelo (also Carite)

633. Grammadenia sintenisii (Urban) $\mathrm{Mez}$

650. Styrax portoricensis Krug \& Urban, palo de jazmín (also Carite)

689. Brunfelsia lactea Krug \& Urban, vega blanca (also Carite and Monte Torito near Cayey)

690. Brunfelsia portoricensis Krug \& Urban

\section{Other Trees Endemic to Puerto Rico}

This list contains 45 tree species of the Caribbean National Forest endemic to Puerto Rico but not confined to this National Forest. Many 
of these grow wild also in one or more Commonwealth Forests. Though local on this island, many occur in sufficient numbers that they are not rare. Two are also in Vieques, and 1 also has been found in St. Croix.

Two additional endemic species have been planted in the Caribbean National Forest: 151. Montezuma speciosissima Sessé \& Moc., maga. 389. Sabinea florida (Vahl) DC., retama, wattapania.

The number of endemic species has been reduced slightly by reduction to synonymy under widely ranging species. Also, a few former endemics have been found on other islands.

4. Acrocomia media O. F. Cook, corozo, prickly-palm, Puerto Rico acrocomia

9. Roystonea borinquena O. F. Cook, palma real, royalpalm, Puerto Rico royalpalm (not rare; also Vieques and St. Croix)

49. Ocotea moschata (Meisn.) Mez, nuez moscada (not rare)

57. Hirtella rugosa Pers., icaquillo (not rare)

129. Sapium laurocerasus Desf., tabaiba (not rare)

165. Rheedia portoricensis Urban, palo de cruz (not rare; also Vieques)

177. Daphnopsis philippiana Krug \& Urban, majagua brava (not rare)

185. Calyptranthes krugii Kiaersk., limoncillo (not rare)

191. Eugenia stahlii (Kiaersk.) Krug \& Urban, guayabota (not rare)

196. Calycogonium squamulosum Cogn., jusillo (not rare)

197. Heterotrichum cymosum (Wendl.) Urban, camasey peludo (not rare)

222. Cordia borinquensis Urban, muñeco (not rare)

248. Rondeletia portoricensis Krug \& Urban, juan tomás (not rare)

255. Nephelea portoricensis (Spreng.) Tryon, helecho gigante espinoso, tree-fern (not rare)

256. Alsophila bryophila Tryon, helecho gigante de la sierra, tree-fern (not rare)

280. Piper blattarum Spreng., higuillo (not rare).

301. Urera chlorocarpa Urban, ortiga, stinging nettle

311. Coccoloba pyrifolia Desf., uvera (not rare)

312. Coccoloba rugosa Desf., ortegón

334. Nectandra sintenisii $\mathrm{Mez}$, laurel amarillo (not rare)

336. Ocotea portoricensis Mez, laurel de paloma (not rare; reported long ago from Cuba)

411. Simarouba tulae Urban, aceitillo cimarrón (not rare)
420. Byrsonima wadsworthii Little, almendrillo (not rare)

472. Maytenus elongata (Urban) Britton

485. Meliosma obtusifolia (Bello) Krug \& Urban, arroyo (collected long ago in Luquillo Mountains)

515. Ternstroemia stahlii Krug \& Urban, mamey del cura (not rare)

516. Ternstroemia subsessilis (Britton) Kobuski

522. Pleodendron macranthum (Baill.) v. Tiegh., chupacallos (collected last in 1940)

555. Calyptranthes portoricensis Britton

568. Eugenia eggersii Kiaersk. guasábara

584. Psidium sintenisii (Kiaersk.) Alain, hoja menuda

605. Miconia pachyphylla Cogn., camasey racimoso (not rare)

607. Miconia pycnoneura Urban, camasey (not rare)

611. Miconia sintenisii Cogn., camasey (not rare)

619. Tetrazygia biflora (Cogn.) Urban, camasey (not rare)

620. Tetrazygia stahlii Cogn., camasey

624. Dendropanax laurifolius (E. March.)

R. C. Schneid., gongolí (not rare)

625. Didymopanax gleasonii Britton \& Wilson, yuquilla

631. Ardisia glauciflora Urban, mameyuelo

635. Wallenia pendula (Urban) Mez, jacanillo

652. Symplocos micrantha Krug \& Urban, aceitunilla

679. Callicarpa ampla Schauer, capá rosa (recorded long ago from St. Thomas)

696. Solanum drymophilum O. E. Schulz, erubia

743. Psychotria maleolens Urban, cachimbo de gato (not rare)

750. Eupatorium portoricense Urban, guerrero (not rare; also Vieques)

\section{Trees Rare in Puerto Rico but Native Beyond}

This list contains 22 tree species of the Caribbean National Forest classed as rare in Puerto Rico but native also in other islands beyond, or rare nonendemic species. These border or peripheral species found nowhere else in the United States merit protection here, though not in danger of extinction.

42. Beilschmiedia pendula (Sw.) Benth. \& Hook. f., guajón

52. Hernandia sonora L., mago

56. Weinmannia pinnata L., oreganillo 
254. Cyathea wilsonii (Hook.) Proctor, helecho gigante, tree-fern

300. Urera caracasana (Jacq.) Gaud., ortiga colorada, stinging nettle (not found in recent years)

325. Aniba bracteata (Nees) Mez, canelillo

339. Persea urbaniana Mez, aguacatillo

341. Phoebe montana (Sw.) Griseb., avispillo

353. Prunus occidentalis Sw., almendrón,

West Indies laurelcherry

417. Bunchosia glandulifera (Jacq.) H.B.K., café falso

421. Malpighia fucata Ker, palo bronco

450. Sapium jamaicense Sw., tabaiba

489. Rhamnus sphaerosperma Sw., West Indian buckthorn
510. Ouratea striata (v. Tiegh.) Urban

511. Cleyera albopunctata (Griseb.) Krug \& Urban

528. Laetia procera (Poepp. \& Endl.) Eichl., talantrón

529. Lunania buchii Urban

593. Conostegia hotteana Urban \& Ekman

599. Miconia affinis DC., camasey (not collected by authors)

683. Cornutia pyramidata L. (collected in Luquillo Mts. in 1881)

695. Solanum antillarum O. E. Schulz

724. Exostema sanctae-Iuciae (Kentish) Britten (collected by Alain Liogier in 1963)

\section{SUMMARY}

The National Forests contain and preserve trees of many species that are classed as rare or local in distribution within the country. Special areas within the National Forests give further protection. Examples are Research Natural Areas, Experimental Forests, Wildernesses, Primitive Areas, Scenic Areas, and Botanical Areas.

Rare and local trees in the National Forests of continental United States include 14 species of hardwoods and 26 of conifers and several varieties. These are listed with names of the National Forests.

Additional border or peripheral species from northwestern Mexico, including 12 of hardwoods, extend northward into the Coronado Na- tional Forest of southeastern Arizona and southwestern New Mexico or beyond.

A few tree species are rare and local near their northwestern limits within the National Forests of southeastern Alaska.

The Caribbean National Forest in northeastern Puerto Rico contains the largest number of species of native trees anywhere in the National Forest System, 225. Of these, 90 tropical tree species are classed as endemic or rare.

Nine tree species and 6 additional varieties on preliminary lists of proposed endangered and threatened plant species of continental United States grow wild within the National Forests. This report is the third in a series on rare and local trees. 


\section{LITERATURE CITED}

Ball, Carleton R.

1943. Salix floridana Chapman a valid species. J. Arnold Arbor. 24: 103-106, illus.

Browne, Edward T., Jr.

1974. A preliminary report on the vascular flora of Sylamore Ranger District, Ozark National Forest, Stone Co., Arkansas. Castanea 39: 170-188.

Channell, R. B., and C. E. Wood, Jr.

1962. The Leitneriaceae in the southeastern United States. J. Arnold Arbor. 43: 435-438.

Clarkson, Roy B.

1966. The vascular flora of the Monongahela National Forest, West Virginia. Castanea 31: 1-119, illus.

Dayton, William A.

1943. Kelsey locust, Robinia kelseyi Hort. ex Hutchins. Am. Midl. Nat. 30 : 504-509, illus.

Duncan, Wilbur $\mathrm{H}$.

1950. Quercus oglethorpensis-range extensions and phylogenetic relationships. Lloydia 13: 243-248, map.

Federal Committee on Research Natural Areas.

1968. A directory of research natural areas on federal lands of the United States of America. 129 p. U.S. Gov. Print. Off., Washington, D.C.

Fernald, M. L.

1945. Some North American Corylaceae (Betulaceae). I. Notes on Betula in eastern North America. Rhodora 47 : 303-329, illus.

Franklin, Jerry F., Frederick C. Hall, C. T. Dyrness, and Chris Maser.

1972. Federal research natural areas in Oregon and Washington: a guidebook for scientists and educators. USDA For. Serv., Pac. Northwest For. Exp. Stn.

Grifin, James R., and William B. Critchfield.

1972. The distribution of forest trees in California. USDA For. Serv. Res. Pap. PSW-82, 114 p. maps (1973).

Johnson, A. G.

1954. Betula lenta var. uber Ashe. Rhodora 56: 129-131.

Jones, Samuel B., Jr.

1974. The flora and phytogeography of the Pine Mountain region of Georgia. Castanea 39: 113 149 , illus.

Kopp, Lucille F.

1966. A taxonomic revision of the genus Persea in the western hemisphere. Mem. N.Y. Bot. Gard. 14(1) : 1-117, illus.

Kurz, Herman, and Robert K. Godfrey.

1962. Trees of northern Florida. 311 p., illus. Univ. Fla. Press, Gainesville.

Little, Elbert L., Jr.

1950. Southwestern trees. U.S. Dep. Agric., Agric. Handb. 9, 109 p., illus.

Little, Elbert L., Jr.

1953. Check list of native and naturalized trees of the United States (including Alaska). U.S. Dep. Agric. Handb. 41, 472 p.

Little, Elbert L., Jr.

1970a. Names of New World cypresses (Cupressus). Phytologia 20:429-445, illus.

Little, Elbert L., Jr.

1970b. Relationships of trees of the Luquillo Experimental Forest. Ch. B-3, p. B-47-58. In Odum, Howard T., and Robert F. Pigeon, eds. A tropical rain forest; a study of irradiation and ecology at
El Verde, Puerto Rico. U.S. A.E.C., Washington, D.C.

Little, Elbert L., Jr.

1971a. Atlas of United States trees. Volume 1, Conifers and important hardwoods. U.S. Dep. Agric. Misc. Publ. 1146, 9 p. (313 maps, folio).

Little, Elbert L., Jr.

1971b. Endemic, disjunct and northern trees in the the Southern Appalachians. P. 249-290, illus. (maps). In Holt, Perry C., ed. The distributional history of the biota of the Southern Appalachians. Part II. Flora. Va. Polytech. Inst. State Univ. Res. Div. Monogr. 2.

Little, Elbert L., Jr.

1975a. Rare and local conifers in the United States.

U.S. Dep. Agric. Conserv. Res. Rep. 19, 25 p., illus.

Little, Elbert L., Jr.

1975b. Our rare and endangered trees. Am. For. $81(7)$ : 16-21, 55-57, illus. (July).

Little, Elbert L., Jr.

1976a. Rare tropical trees of South Florida. U.S. Dep. Agric. Conserv. Res. Rep. 20, 20 p., illus.

Little, Elbert L., Jr.

1976b. Atlas of United States trees. Volume 3. Minor western hardwoods. U.S. Dep. Agric. Misc. Publ. 1314, 13 p., illus. (290 maps).

Little, Elbert L., Jr.

1977. Atlas of United States trees. Volume 4. Minor eastern hardwoods. U.S. Dep. Agric. Misc. Publ. illus. (230 maps).

Little, Elbert L., Jr., and Frank H. Wadsworth.

1964. Common trees of Puerto Rico and the Virgin Islands. U.S. Dep. Agric., Agric. Handb. 249, 548 p., illus.

Little, Elbert L., Jr., and Roy O. Woodbury.

1976. Trees of the Caribbean National Forest, Puerto Rico. USDA For. Serv. Res. Pap. ITF-20, $27 \mathrm{p}$.

Little, Elbert L., Jr., and Roy O. Woodbury, and Frank H. Wadsworth.

1974. Trees of Puerto Rico and the Virgin Islands second volume. U.S. Dep. Agric., Agric. Handb. 449,1024 p., illus.

Mazzeo, Peter M.

1974. Betula uber-what is it and where is it? Castanea 39: 273-278, illus.

Mohlenbrock, Robert $\mathrm{H}$.

1976. Woody plants of the Ocala National Forest, Florida. Castanea $41: 309-319$.

Moran, Reid.

1977. Plant notes from the Sierra Juarez of Baja California, Mexico. Phytologia 35: 205-215.

Ogle, Douglas W., and Mazzeo, Peter.

1975. Betula uber found. Castanea $40: 365$.

Ogle, Douglas W., and Mazzeo, Peter.

1976. Betula uber, the Virginia round-leaf birch, rediscovered in southwest Virginia. Castanea 41: 248-256, illus.

Reed, Clyde F.

1975. Betula uber (Ashe) Fernald rediscovered in Virginia. Phytologia 32: 305-311, illus.

Smith, A. C.

1947. The families Illiciaceae and Schisandraceae. Sargentia 7, 224 p., illus.

Smithsonian Institution, Secretary.

1975. Report on endangered and threatened plant species of the United States presented to the Congress of the United States of America by the Sec- 
retary, Smithsonian Institution. U.S. 94th Congr. 1st Sess., House Doc. No. 94-51, Ser. No. 94-A, $200 \mathrm{p}$.

Sudworth, George B.

1913. Forest atlas. Geographic distribution of North American trees. Part I. Pines. U.S. Dep. Agric. For. Serv., 36 maps (folio).

U.S. Department of the Interior, Fish and Wildlife Service.

1976. Endangered and threatened wildlife and plants. Proposed endangered status for some 1700 U.S. vascular plant taxa. Federal Register vol. 41, no. 117 (June 16, 1976) : 24524-24572.

U.S. Department of Agriculture, Forest Service.

1970a. Framework for the future. Forest Service objectives and policy guides. U.S. Dep. Agric. For. Serv., 16 p.

U.S. Department of Agriculture, Forest Service.

1970b. Search for solitude, our wilderness heritage. U.S. Dep. Agric. Programs Aid 942, 32 p., illus.

U.S. Department of Agriculture, Forest Service.
1971. National Forest wilderness and primitive areas. U.S. Dep. Agric. Serv. FS-25, 6 p.

U.S. Department of Agriculture, Forest Service.

1977. National Forest System: areas as of September 30, 1976. 41 p. U.S. Gov. Print. Off.

Viereck, Leslie A., and Elbert L. Little, Jr.

1972. Alaska trees and shrubs. U.S. Dep. Agric., Agric. Handb. 410, 262 p., illus.

Viereck, Leslie A., and Elbert L. Little, Jr.

1975. Atlas of United States trees. Volume 2. Alaska trees and common shrubs. U.S. Dep. Agric. Misc. Publ. 1293, 19 p. (105 maps).

Ward, Daniel B.

1963. Trees of northern Florida [book review]. Castanea 28: 172-176.

Wells, Philip V., and R. Roy Johnson.

1964. Vauquelinia pauciflora (Rosaceae) from Guadalupe Canyon, Arizona: a species of trees newly reported for the United States. Southwest. Nat. 9: 151-154. 

